\title{
Orbital Compression Syndrome in a Child with Sickle Cell Anaemia:A Case Report And Review of Literature
}

\author{
Panda PK ${ }^{1}$
}

\begin{abstract}
Vaso-occlusive crises in sickle cell disease commonly involve bone marrow of the long bones and vertebrae. Involvement of bones with less marrow space, including the bones of the orbit, is reported rarely in the literature. The present case is a six year old boy, a known case of sickle cell disease, who presented with acute onset right upper and lower eyelid swelling, restriction of extraocular movement and pain. USG orbit showed a retroorbital haemorrhage compressing on the orbit, probably due to orbital bone infarction. The child was managed successfully with red blood cell transfusion and intravenous antibiotics, without steroids and surgical intervention. This report highlights the importance of maintaining a high index of suspicion in patients with known sickle cell disease presenting with pain, orbital swelling and restriction of ocular movement. Timely red blood cell transfusion only may be sufficient for uneventful recovery, without steroids or surgical intervention. Expedient diagnosis of orbital compression syndrome in children with sickle cell disease is crucial because this is a potentially sightthreatening entity.
\end{abstract}

Key words: orbital compression syndrome; sickle cell disease

\section{Introduction}

S ickle cell disease is a haemoglobinopathy characterised by chronic haemolytic anaemia. It is due to a single amino acid substitution on the $\beta$ chain of haemoglobin. ${ }^{1}$ This autosomal recessive disease usually manifests in homozygous or compound heterozygous state. ${ }^{1}$ In either case, the relative amount of abnormal haemoglobin $(\mathrm{HbS})$ is enough to allow red blood cells to assume a sickled shape, when the plasma oxygen content or $\mathrm{pH}$ decreases. ${ }^{1}$ The sickled red blood cells can occlude microcirculation and cause infarction to tissues downstream, which is called vasoocclusive crisis $^{2}$. These vasoocclusive crises usually present as acute chest syndrome, dactylitis, priapism and stroke. Vaso-occlusive crises may also involve bone marrow of the long bones and vertebrae. ${ }^{2}$ Involvement of bones with less marrow space, including the bones of the orbit, is extremely rare in the literature. ${ }^{3}$ Other ophthalmic involvement by sickle cell disease in the form of anterior segment ischemia, glaucoma, angioid streaks, and retinopathy are more common. ${ }^{4}$ Orbital infarction due to sickle cell disease causes periorbital tenderness, swelling and erythema. Soft tissue swelling of the orbit can also result in proptosis, restriction
${ }^{1}$ Prateek Kumar Panda, Senior Resident, Department of Paediatrics, All India Institute of Medical Sciences, New Delhi, India.

\section{Address for correspondence \\ Prateek Kumar Panda \\ Department of Paediatrics \\ All India Institute of Medical Sciences \\ New Delhi, India \\ E-mail: drprateekpanda@gmail.com}

\author{
Acknowledgements: None \\ Funding: Nil \\ Conflict of Interest: None \\ Permission from IRB: Not Submitted
}

\section{How to cite}

Panda PK. Orbital Compression Syndrome in a Child with Sickle Cell Anaemia: A Case Report and Review of Literature. J Nepal Paediatr Soc 2018;38(3):200-2.

doi: http://dx.doi.org/10.3126/jnps.v38i3.19328

Submitted on: 2018-03-06

Accepted on: 2020-02-03

This work is licensed under a Creative Commons Attribution 3.0 License. 
of extraocular movements and potentially, compressive optic neuropathy, constituting orbital compression syndrome. ${ }^{5}$ Hence, timely correct diagnosis of such disease is crucial for preserving sight of the person. We are herewith presenting such a case of orbital compression syndrome, probably caused by orbital bone infarction in a six year old boy with sickle cell disease, managed successfully with blood transfusion and intravenous antibiotics only, without steroid or surgical intervention.

\section{Case Report}

This six year old boy was a case of sickle cell disease (HbSS) diagnosed at the age of one year, on the basis haemoglobin electrophoresis. Thereafter, the child was under regular follow up from our institute with blood transfusions as required, usually three to four times in a year. The child was also on folic acid supplementation, to maximise erythropoisis. In the current illness, the child presented with history of two days of progressive swelling of his right upper and lower eyelids (Figure 1), associated with pain and restriction of extra ocular movement. He had only minimal mucopurulent discharge. The child did not complain of any visual impairment, except for occasional double vision. He had no systemic symptoms, such as fever, cough, cold, rhinorrhoea, chest pain, pain abdomen, headache, or pain in other sites of body. There was no recent history of chalazion, bug bite, ocular or head trauma. The child was admitted one year back with acute chest syndrome and was managed successfully with blood transfusion and IV antibiotics.

On examination, his visual acuity was $6 / 6$ in both eyes, although he could not open his right eye without manual manipulation. He had mild proptosis and prominent right upper and lower eyelid swelling with erythema. His left eye was normal. His pupils measured $4 \mathrm{~mm}$ in the dark and $2 \mathrm{~mm}$ in the light with no relative afferent papillary defect. He had restricted extraocular movement in up gaze in right eye and he was orthophoric. His intraocular pressure was normal. Anterior segment examination revealed mild conjunctival injection and chemosis in the palpebral and temporal bulbar conjunctivae. Fundus examination was normal. On systemic examination, the child had pallor, haemolytic facies, hepatomegaly and spleen tip was palpable. His complete blood count showed white blood cell count of $7,600 /$ cumm, haemoglobin of $8.0 \mathrm{gram} /$ deciliter, reticulocytosis of $5.0 \%$ and normal platelet count. Abnormal red blood cell morphology was noted on the peripheral smear, including sickled red blood cells. USG of right orbit showed a retro-orbital subperiosteal hematoma of size $1.8 \mathrm{~cm} \times 1.5 \mathrm{~cm}$ compressing on the orbital tissue (Figure 2). The child was administered intravenous fluid for hydration and one unit of packed red blood cell transfusion. He was also started on intravenous ceftriaxone and vancomycin initially, as orbital cellulitis could not be ruled out unequivocally. However, the child showed significant improvement in upcoming two days with decrease in swelling and erythema of eyelids, improvement in eye opening and extraocular movement. So, computed tomography and any further imaging, surgical intervention or steroid was deferred. The child was discharged after four days of hospital stay with normal vision and mild residual eyelid swelling.

\section{Discussion}

Orbital compression syndrome due to subperiosteal haemorrhages and orbital bone infarction is a rare complication of sickle cell disease. ${ }^{5}$ It usually presents in persons with age less than 20 years with male predominance. Sokol et al. have described two similar cases due to infarction of greater wing of sphenoid. ${ }^{2}$ Orbital infarction presents with acute periorbital pain and swelling, and if remains untreated then may impair vision. ${ }^{6}$ The inflammatory response generated by infarcted bone can rapidly spread to the periorbital soft tissue causing proptosis. ${ }^{7}$ A unique feature of orbital bone infarction is the formation of haematoma, the occurrence of which is thought to be related to local vessel wall necrosis and subsequent extravasation of blood. ${ }^{7}$ These haematomas along with the inflammatory swelling also contribute to proptosis, ophthalmoplegia, conjunctival chemosis, corneal hypoesthesia and optic nerve dysfunction (orbital compression syndrome). ${ }^{7}$ Rarely orbital bone infarction can be painless, as in a case report described by Mc Bride et al. ${ }^{1}$

Most of these cases, if timely diagnosed, can be managed successfully with packed red blood cell transfusion or exchange transfusion. Although, many of the available literature have reported use of intravenous antibiotics and steroid, no standard treatment guideline strongly recommends these two drugs. Surgical decompression can be avoided in most cases.

\section{Conclusion}

This report highlights the importance of maintaining a high index of suspicion in patients with known sickle cell disease presenting with pain, orbital swelling and restriction of ocular movement. Timely red blood cell transfusion only may be sufficient for uneventful recovery, without steroids or surgical intervention. Expedient diagnosis of orbital bone infarction and orbital compression syndrome in children with sickle cell disease is crucial because this is a potentially sightthreatening entity. 


\section{References}

1. McBride $\mathrm{CL}$, Mai K-BT, Kumar KS. Orbital Infarction due to Sickle Cell Disease without Orbital Pain. Case Rep Ophthalmol Med. 2016;2016:5867850. DOI: 10.1155/2016/5867850

2. Sokol JA, Baron E, Lantos G, Kazim M. Orbital compression syndrome in sickle cell disease. Ophthal Plast Reconstr Surg. 2008;24(3):181-4.

3. Al-Suleiman AM. Diagnosis: Orbital Compression Syndrome in Sickle Cell Disease. Frayha H, editor. Ann Saudi Med 2006;26(1):76-76.

4. Ganesh A, William RR, Mitra S, Yanamadala S, Hussein SS, Al-Kindi $\mathrm{S}$, et al. Orbital involvement in sickle cell disease: A report of five cases and review literature. Eye 2001;15(6):774-80. DOI: 10.1038/ eye.2001.248
5. Karacostas D, Artemis N, Papadopoulou M, Christakis J. Epidural and Bilateral Retroorbital Hematomas Complicating Sickle Cell Anemia. Am J Med Sci Eye (Lond). 2001;15(6):774-80. DOI: 10.1097/00000441199108000-00008

6. Ganesh A, William RR, Mitra S, Yanamadala S, Hussein SS, Al-Kindi S, et al. Orbital involvement in sickle cell disease: a report of five cases and review literature. Eye (Lond) 2001;15(Pt 6):774-80.

7. Mark Ventocilla. Ophthalmologic Manifestations of Sickle Cell Disease: Overview, Posterior Segment Abnormalities, Anterior Segment Abnormalities. 2016 Jun 3 [cited 2018 Mar 4].

8. Sokol JA, Baron E, Lantos G, Kazim M. Orbital Compression Syndrome in Sickle Cell Disease. Ophthal Plas Reconstr Surg. 2008;24(3):181-4. DOI: 10.1097/IOP.0b013e31816b960e 